\title{
Research on Mechanism and Emergency Countermeasures of Highway Landslide of Crest EHV Power Tower
}

\author{
ZHANG Hong-ri ${ }^{1,2, a}$, WANG Gui-yao ${ }^{1, b}$, LAN Su-liang ${ }^{2, c}$, SHA Lin-chuan ${ }^{1, d}$
}

1. School of Civil and Architecture Engineering, Changsha University of Science \& Technology, Changsha 410076, China;

2. Guangxi Transportation Research Institute, Nanning 530007, China

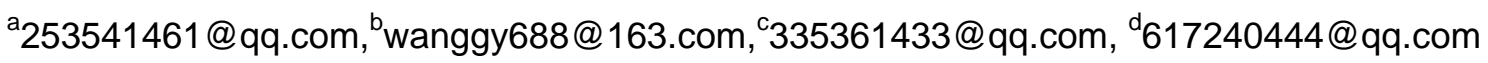

Keywords: Emergency Treatment; Landslide; High-voltage tower; Micro piling; Back pressure

\begin{abstract}
Landslide protections are ultimately races against time. Through analyzing the landslide, we can take prompt measures to prevent further decline and avoid heavy losses. By analyzing highway landslide of crest EHV power tower formation mechanism, calculating and analyzing landslide stability, this paper suggests that landslide Emergency Treatment should take drainage, back pressure, micro piles and grouting methods. By displacement monitoring, the results show that the landslide formation mechanism analysis is reasonable and timely. Appropriate measures are taken, slope displacement has been fundamentally controlled, significant and irreparable losses are avoided. That earns the valuable time for the next step work, and plays a significant and reference role in landslide emergency treating.
\end{abstract}

\section{Engineering situation}

A secondary road is an important part of national highway, which is an important north-south link channel. K62+000 K90+500 sections belong to tectonic denudation - the unit erosion topography of low hills, and there are lots of deep cutting. On the top of the left slope of K70+490 there is an EHV tower belonging to Yan Chong, a line which is west to east south trunk channel. The slope is abrupt and have an angle about $40^{\circ}$ with the horizontal plane. The maximum height of slope is 37m. Began in July 2013 in the construction segment, the largest excavation slope height is about $27 \mathrm{~m}$. The slope did not appear slump. On November 21, 2014, after a year and a half after the resumption of construction. On November 25 when the basic excavation near the design elevation, slope surface appeared multiple fractures, local producing slide. Its $500 \mathrm{kv}$ DC, which is yet to replace the line.The project blackouts caused economic losses and social impact will be great, so it's rush to deal with an emergency work.

\section{Geological conditions}

\subsection{Stratum}

The covering of landslide is cohesive soil $\left(\mathrm{Q}_{4}{ }^{\mathrm{dl}+\mathrm{el}}\right)$, can be hard plastic-like, with an average thickness of $3.0 \mathrm{~m}$. Underlain by Devonian shale $\left(\mathrm{D}_{2} \mathrm{y}\right)$ : fine structure, flaggy structure, joints fractured, rock hardness moderate, hammering depression, fragile, strong weathering average thickness 3.0m, the lower Intermediary Weathered Sandstone.

\section{2 rock mass discontinuity and groundwater}

Rock tendency is generally $195 \sim 210^{\circ}$, and dip is $33 \sim 45^{\circ}$. The angle of rock slope inclination and route is $105 \sim 110^{\circ}$. In the development of a weathered joints $\mathrm{J} 1$, which occurrence is $315^{\circ} \angle 27^{\circ}$, festival grounds K70 + 400 side K70 + 520 slope toe to strongly weathered, iron red rock surface rendering, broken joints with thick $50 \mathrm{~cm}$. Fracture zone is mainly composed of sandy shale crusher. Cohesion is small between the joint plan. The topography of landslide is higher, and in half a month there is without rainfall in the slope excavation period recently, so slope stability was less affected by groundwater. 


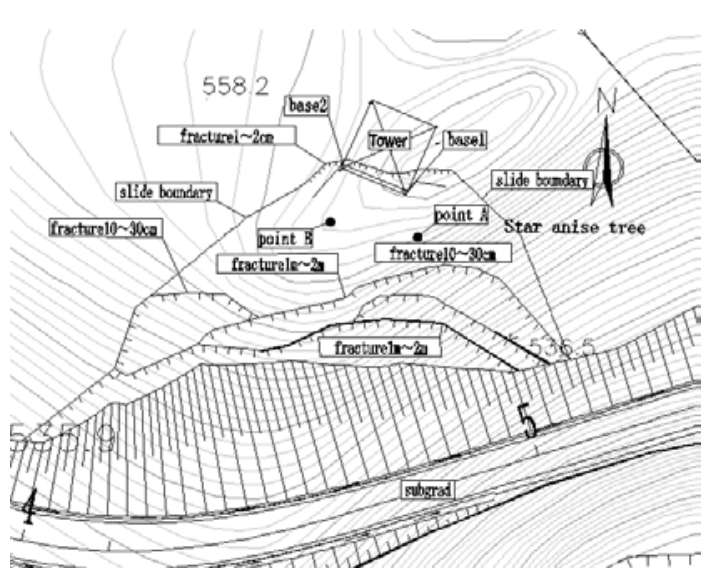

Figure 1 Plan of the landslide

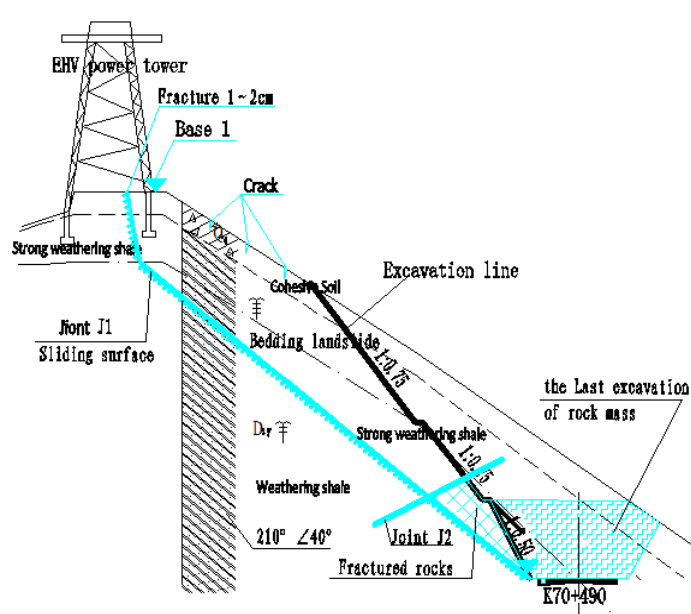

Figure 2 The elevation of landslide

\section{Analysis of the mechanism and stability of landslide formation}

\subsection{Landslide morphological characteristics and scale}

The K70+490 section landslide, upper narrow and lower width, its shape is similar to a "bell" shape, as shown in Fig.1. The upper landslide of crack appears small displacement, and the inside of tower foundation has a continuous crack with $30 \mathrm{~m}$ long, $1 \mathrm{~cm}$ across. The central part can keep the original sequence, but reticulation cracks appears where distance from slope top $10 \mathrm{~m}, 15 \mathrm{~m}, 20 \mathrm{~m}$, as shown in figure 2. The cracks are $10 \sim 20 \mathrm{~cm}$ wide, and landslide among the cracks have apparently displacement. Geotechnical engineering of other central surface vegetation and disorderly sliding body, which is not obvious loose or abnormal fracture and does not appear "drunk Lin" and "Saber shape tree".

\subsection{Landslide Research}

The remaining level of the section of slope excavation, up to a year's time it did not appear landslide. The slope excavation remains last one level and produce slide. At the bottom of slope, there is the rock slumping from upper part, which is analyzed that this place is the main landslide that can be cut exports. According to the case of micro piles, at the depth of $6 \sim 8 \mathrm{~m}$ drilling caused grout leakage. multiple holes leakage flow direction is consistent with the analysis of rock occurrence, suggest that joints (structural surface) development judged to be slope slip surface. According to the actual rock movement direction of the slope perspective, the sliding direction is consistent with the tendency of the rock of $195 \sim 210^{\circ}$, with the oblique intersect of the line.

By the analysis above shows that the landslide is soft rock bedding landslide with the sandy shale in the main, Counting from the toe of the slide surface, along the structure surface J1 develop to weathered ceiling, which near the base of the tower to a depth of about $7 \mathrm{~m}$. Landslide is about $140 \mathrm{~m}$ long, the landslide zone $65 \mathrm{~m}$ wide, the deformation zone $75 \mathrm{~m}$ wide, the thickness of $10 \mathrm{~m} \sim$ $16 \mathrm{~m}$, the volume is nearly 15 million cubic meter, belong a medium-sized thin layer trailed landslide. Which belongs to medium-sized middle traction landslide. The reason for the landslide instability profiles: internal reason is for the steep slope, rock occurrence bedding, joint development, rock crushing; external causes for slope protection is not timely, and artificial excavation toe and so on.

\subsection{Parameter selection and calculation results}

\subsubsection{Analysis of calculation parameters}

According to analysis of laboratory tests to the strength of rock and soil, weathered shale uniaxial compressive strength of standard value is $5.60 \mathrm{MPa}$, as soft rock ${ }^{[1-3]}$; according to drilling core samples and actual situation slip surface, the structural plane (joint plane) is without fillers or filler is crushing weathered shale fragments. So the structural plane is defined as a combination of poor $^{[1-4]}$. According to the specification ${ }^{[2-3]}$, cohesion is taken $55 \mathrm{kPa}$, internal friction angle is taken $21^{\circ}$; Mechanical parameters of the recommended value can be seen in Table1. 
Table1.The selected value of mechanical parameters

\begin{tabular}{|c|c|c|c|c|c|c|c|c|c|}
\hline \multirow[b]{2}{*}{$\begin{array}{l}\text { Lithology } \\
\text { and code }\end{array}$} & \multicolumn{2}{|c|}{ Density $\gamma\left(\mathrm{kN} / \mathrm{m}^{3}\right.$} & \multicolumn{2}{|c|}{$\begin{array}{c}\text { CohesionC } \\
(\mathrm{kPa})\end{array}$} & \multicolumn{2}{|c|}{$\begin{array}{c}\text { Internal } \\
\text { Friction } \varphi\left({ }^{\circ}\right)\end{array}$} & \multirow{2}{*}{$\begin{array}{l}\text { Frictio } \\
\mathrm{n} \\
\text { Factor } \\
\mu\end{array}$} & \multirow{2}{*}{$\begin{array}{c}\text { Foundatio } \\
n \\
\text { Coefficie } \\
n t \\
\mathrm{~K}(\mathrm{MPa} / \mathrm{m} \\
) \\
\end{array}$} & \multirow{2}{*}{$\begin{array}{c}\text { Bearin } \\
\mathrm{g} \\
\text { capacit } \\
\mathrm{y} \\
\mathrm{f}_{\mathrm{ao}}(\mathrm{kPa} \\
) \\
\end{array}$} \\
\hline & $\begin{array}{c}\text { natura } \\
\quad 1\end{array}$ & $\begin{array}{c}\text { saturate } \\
\text { d }\end{array}$ & $\begin{array}{c}\text { natura } \\
1\end{array}$ & $\begin{array}{c}\text { residua } \\
1\end{array}$ & $\begin{array}{c}\text { natura } \\
\quad 1\end{array}$ & $\begin{array}{c}\text { residua } \\
1\end{array}$ & & & \\
\hline $\begin{array}{c}\text { Cohesive } \\
\text { Soil }\end{array}$ & 16.7 & 19 & 35.4 & 2.8 & 17.5 & 8.4 & 0.4 & 40 & 200 \\
\hline $\begin{array}{c}\text { Strong } \\
\text { weathering } \\
\text { shale }\end{array}$ & 22.2 & - & 277 & - & 23.2 & - & 0.43 & 100 & 300 \\
\hline $\begin{array}{c}\text { weathering } \\
\text { shale }\end{array}$ & 23.5 & 25.0 & 719 & & 37.5 & & 0.77 & 400 & 800 \\
\hline $\begin{array}{c}\text { Rock mass } \\
\text { Discontinuit } \\
\mathrm{y} \\
\end{array}$ & & & & 56 & & 20 & 0.38 & & \\
\hline
\end{tabular}

\subsubsection{Analysis of the calculation results}

After the sliding slope, according to the foregoing analysis on the sliding mechanism, not considering the impact of groundwater on slope stability, we use "building slope engineering and technical specifications" recommended limit equilibrium method formula A03-1, to conduct landslide stability calculation. According to the power sector to provide a single wide angle tower vertical force $711 \mathrm{kN}$, horizontal force $126 \mathrm{kN}$, which acts directly on the rock. Calculation of K70 +490 typical section show that the landslide safety factor is 0.95 , which is less than 1.0. The slope is in an unstable state and can generate a high-speed slide at any time, endangering the safety of the upper electrical towers.

\section{Temporary emergency measures}

Before the completion of permanent support program, in order to ensure the safe operation of electrical towers, we must focused on the electrical towers and landslides temporary reinforcement. In ensuring the safe operation of electrical towers premise, emergency Treatment programs should be consistent with the principles of practical, easy construction, economical and reasonable.

\subsection{Drain}

Under the effect of rainfall conditions, slope soil bulk density increases. If the slope fissures do not close, it's easy to form rain infiltration channels, reducing shear strength parameters of slope structural surface. Meanwhile rainfall erosion slope, also available from the slope infiltration, accelerates the rate of slope decline ${ }^{[4-5]}$. In order to prevent rainwater corroding slope and rainwater infiltrating crack, on November 28, 2014 on the slope pure mud were used to seal and fill the cracks. And the cracks were covered with the Plastic film. Using the Plastic film to cover the area of sliding slope, it's to prevent rainwater corroding the landslide. Surface slope landslide in vitro, digging drainage ditches and gutters, avoid landslide vitro surface water erosion.

\subsection{Backpressure}

Because of the slope is declining, measures must be taken to reduce the slope sliding force as soon as possible, or increase slope stabilizing force. Backpressure of toe is the method of the most direct and fastest. According to the calculation of backpressure, slope safety factor is 1.05, basically stable, backpressure height is $20 \mathrm{~m}$. In order to complete the backpressure before the rains, backpressure work 24 hours a day, multiple loaders, bulldozers, rollers, transport vehicles conduct rescue operation at the same time from November 27 to December 30. At the end of work, backpressure to elevation 625 (height 22m).

\section{3 Micro-pile and drilling slip casting}

Back pressure can avoid landslides, but The upper part of landslide is clayey soil, and the 
shearing strength is weak. Because of tower, the clayey soil will still slip along the boundary rock. So it should be taken the method to reinforce the base of tower. There are some important problems should be taken attention. Firstly, landslide is in sliding, so construction can not cause large interference to the landslide. Secondly, the height of reinforcement construction of tower foundation is constrained. According to the power requirements, the construction sector must be less than $12 \mathrm{~m}$ height. Thirdly, the job site is limited by the large electrical tower and the steep slope. Finally, there was no large mechanical direct sidewalk to the upper slope. In the process of tower foundation lateral reinforcement, large anti-slide pile require large machinery entering and construction, which is bad for slope, and do not have large mechanical approach conditions. Hand-dug piles is insecurity and slow progress. Anchor cable and anchor stock both need long time to be effective. Micro-piles have some characteristics, such as light construction machinery, construction speed, small construction site, the construction process of the landslide is small, the lateral bearing capacity. The construction process can be combined with geological drilling, grouting drilling multiple roles at the same time, strengthening the foundation of the tower as the main measures to micro pile reinforcement means. Reinforcement of the outer tower $3 \mathrm{~m}, 4 \mathrm{~m}$, respectively staggered arrangement of a row of each micro-pile.

On December 1, 2014, constructors conducted micro-pile. Drilling was used unmixed cement paste instead of using water or cement-sand mortar. On the one hand, the unmixed cement paste will protect wall, lubricate and cool the bit, and accelerate drilling. On the other hand, unmixed cement paste which drilled in the bedrock fissure and the sliding surface leak out. It taken grouting effect, increased the cohesive force and the friction coefficient of the rock mass sliding surface, and effectively increase the slope sliding resistance. Micro-piles design of steel tube+ reinforced + cement association. When drilling was completed decentralization $\varphi 150$ seamless steel pipe, which was $5 \mathrm{~mm}$ thickness, with greater stiffness. After the formation of shear decentralized direct action in place, the rapid increase in landslide stabilizing force. Three reinforcement steel bars with the diameter of $25 \mathrm{~mm}$ were welded together to reinforced beam injection of cement paste. The reinforcement bars with the steel tube formed a strong pile to joins force. Steel beam welded together between the holes with a $75 \mathrm{~cm}$ thick C25 concrete pouring together to form a platform. It enhanced the overall stiffness of the piles. On December 13, 2014, the mini-pile construction is completed. On December 14, 2014, the construction of the platform is completed.

\section{Slope displacement monitoring analysis after the emergency measures}

Setting up settlement and displacement observation points in the earth's surface after landsliding, the observation points shown in figure 1 . The observation results as shown in the figure below.
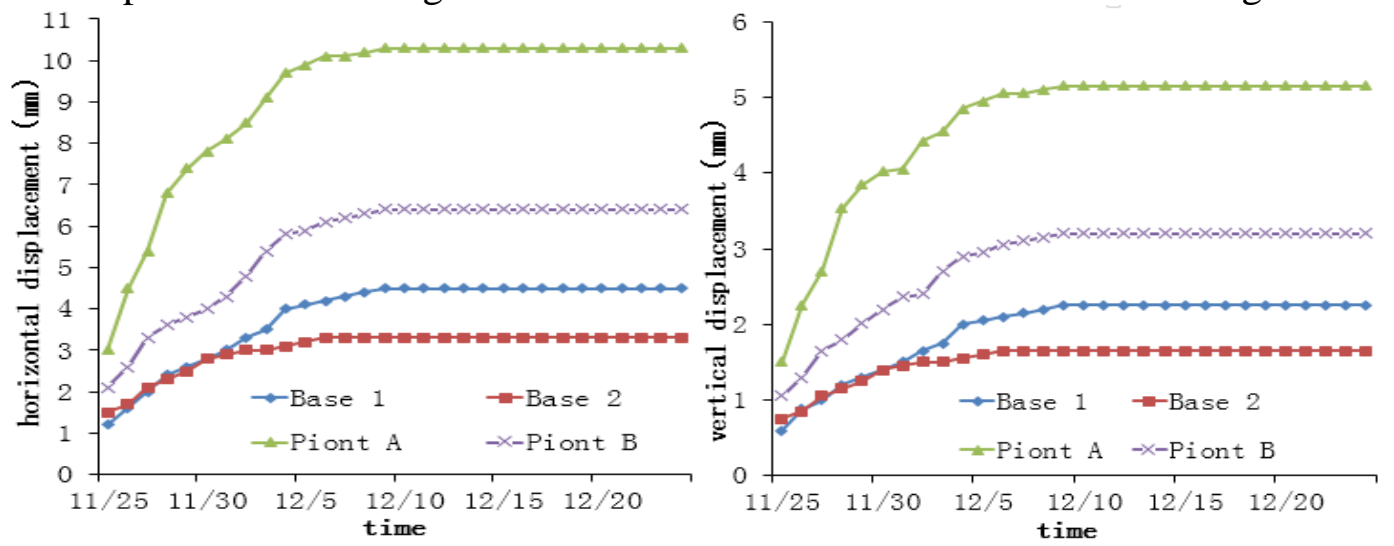

Figure 3 monitoring of horizontal and vertical displacement with time

According to the monitoring data, before the back pressure were constructed, on the slope vertex A and B, the tower foundation 1 and 2, four monitoring stations displacement increased. Obviously, both in horizontal displacement and vertical displacement, and the slope was in the sliding state. After backpressure constructed, the four monitoring displacement was obviously slow, and slope displacement got in control basically. But the effect of inertia of the landslide and the upper shallow stratum in the pylon and its gravity, which caused the shallow sliding along the geotechnical interface, and four displacement monitoring points were still on the rise. From December 1 to 
December 4, it was rainy. The soil of slope was affected by rainfall, and the slide force increased. Sliding resistance loss, slope sliding displacement increased obviously than the previous stage, but the landslide displacement was under control because of the whole landslide slope completely coverage and drainage measures carried out. Micro-piles constructed began from December 1, to December 8, it has finished $70 \%$ of steel pipe down and pile casting. According to four observation point displacement data, the movement of the upper soil landslide and tower foundation also got the basic control and displacement were subtle changes. On December 14, all the construction of pile and platform completed, and on December 25, four monitoring points didn't produce obvious displacement.

\section{Results}

The landslides of under construction highway roadbed, which directly threaten the sound operation of the ultra-high voltage electric in the peak tower, so the key point of landslide disaster is robbing point in time. This article analyzed the landslide mechanism and took drainage, back pressure, micro pile + grouting temporary emergency disposal. At the same time, the whole process of the landslide displacement is monitored. The results showed that:

(1) Landslide mechanism analysis and reasonable, parameters selection and calculation correct, the slope is in an unstable state.

(2) Slope drainage measures properly, dig trenches and the slope coverage, which avoids the slope erosion and infiltration due to the rain. The monitoring data showed that the addition of landslide displacement is small, and large or high speed sliding have not happened.

(3) The backpressure timely, the addition displacement increases rapidly decreasing, and the landslide part basically stable, ultimately the landslide to fall further controlled.

(4) The effect of miniature pile + grouting is obvious, drilling and grouting in the process of pouring pile construction, which is good for filling sliding crack and increasing the sliding resistance of slope , after miniature pile constructed, the internal steel tube pile effect quickly, pouring pile stiffness big, upper landslide displacement been fundamentally controlled,

(5) When landslide is in sliding condition, the emergency treatment, adopting the method of drainage, back pressure and micro pile, should be used. And monitoring the landslide displacement, which is obvious effective and reasonable measures, to avoid the irreparable loss because of the slope slide further. At the same time, it created valuable time for next step work of last landslide permanent reinforcement or pylon removed. It provides great reference significance to other landslide emergency.

\section{Acknowledgments:}

1.Projects(2015AC09017) supported by Science Research and Technology Development of Guangxi

2.Projects(KJ2014-014) supported by Guangxi Transportation Research Institute

\section{References}

[1] GB 50021-2001, Code for investigation of geotechnical engineering (2009) [S].

[2] GB 50330-2013, Technical code for building slope engineering [S].

[3] DZ/T 0219-2006, Technical code for design and construction of Landslide Control Engineering

[4] DZ/T 0218-2006, Specification for investigation of landslide control project [S].

[5] Xie-Dingyi, Lin-Benhai, Shao-Shengjun. Geotechnical Engineering[M].Beijing: Higher Education Press, 2008.

[6]Zhen-Yinren, Chen-Zhuyu, Wang-Gongxian, Ling-Tianqing. Slope and landslide treatment[M]. 
Beijing: The people's traffic press, 2007.

[7]Sun-Shuwei, Zhu-Benzhen, Zheng-Jing. The design method of limit analysis of soil slope resistance of micro pile group based on reinforcement [J]. Chinese Journal of geotechnical engineering, 2010. 11:1671-1677.

[8]BRUCE D A, JURAN I. Drilled and grouted micropiles:state-of-practice review[R]. US Dept of Transportation, Federal Highway Administration, 1997: 1-17.

[9] RICHARDS T D, ROTHBAUER M J. Lateral loads on pinpiles (Micropiles)[J]. Geotechnical Special Publication, 2004,1(7): 158-174. 